\title{
A Ground Beetle, Calleida decora (Fabricius) (Insecta: Coleoptera: Carabidae) ${ }^{1}$
}

D. L. Harris and W. H. Whitcomb ${ }^{2}$

\section{Introduction}

Calleida decora (Fabricius) is a small arboreal ground beetle, predaceous both as larva and adult. Common on various cultivated crops, it is apparently the only carabid to complete its larval development on Florida soybean foliage (Neal 1974). It is believed to be a major factor in suppression of several lepidopterous pests, e.g., velvetbean caterpillar, Anticarsia gemmatalis Hübner, on soybeans.

\section{Synonymy}

Erwin et al. (1977) listed synonyms:
C. cordicollis Putzeys,
C. cyanoptera LeConte, and
C. coeruleipennis Gemminger \& Harold.

\section{Distribution}

Calleida decora is reported from the southeastern United States, extending into the Midwest, Baja California, Mexico, and Belize (Erwin et al. 1977).

\section{Description}

Eggs are round, white, semi-opaque, approximately $0.75 \mathrm{~mm}$ in diameter, covered with sand particles, and attached by a silken thread to a leaf or other available surface such as a stem or twig.

Larvae are active, black, campodeiform (in early stages having no abdominal appendages except cerci), with yellowish-red head capsules. Larvae are approximately $1.5 \mathrm{~mm}$ long at hatching and may grow to $10 \mathrm{~mm}$ total body length prior to pupation. Mean head capsule widths for the three larval instars are $0.60,0.90$, and $1.23 \mathrm{~mm}$ respectively.

Pupae are white, exarate, and approximately 5 mm long. The pupal cell is usually constructed ca. 7 to $15 \mathrm{~mm}$ beneath the soil surface (Hasse 1971).

1. This document is EENY-331 (originally published as DPI Entomology Circular 278), one of a series of Featured Creatures from the Entomology and Nematology Department, Florida Cooperative Extension Service, Institute of Food and Agricultural Sciences, University of Florida. Published: July 2004. This document is also available on Featured Creatures Website at http://creatures.ifas.ufl.edu. Please visit the EDIS Website at http://edis.ifas.ufl.edu. Additional information on these organisms, including many color photographs, is available at the Entomology and Nematology Department website at http://entnemdept.ifas.ufl.edu/.

2. D. L. Harris, Florida Department of Agriculture and Consumer Services - Division of Plant Industry, and W. H. Whitcomb, Entomology and Nematology Department, University of Florida, Gainesville, FL.

The Institute of Food and Agricultural Sciences (IFAS) is an Equal Opportunity Institution authorized to provide research, educational information and other services only to individuals and institutions that function with non-discrimination with respect to race, creed, color, religion, age, disability, sex, sexual orientation, marital status, national origin, political opinions or affiliations. U.S. Department of Agriculture, Cooperative Extension Service, University of Florida, IFAS, Florida A. \& M. University Cooperative Extension Program, and Boards of County Commissioners Cooperating. Larry Arrington, Dean 


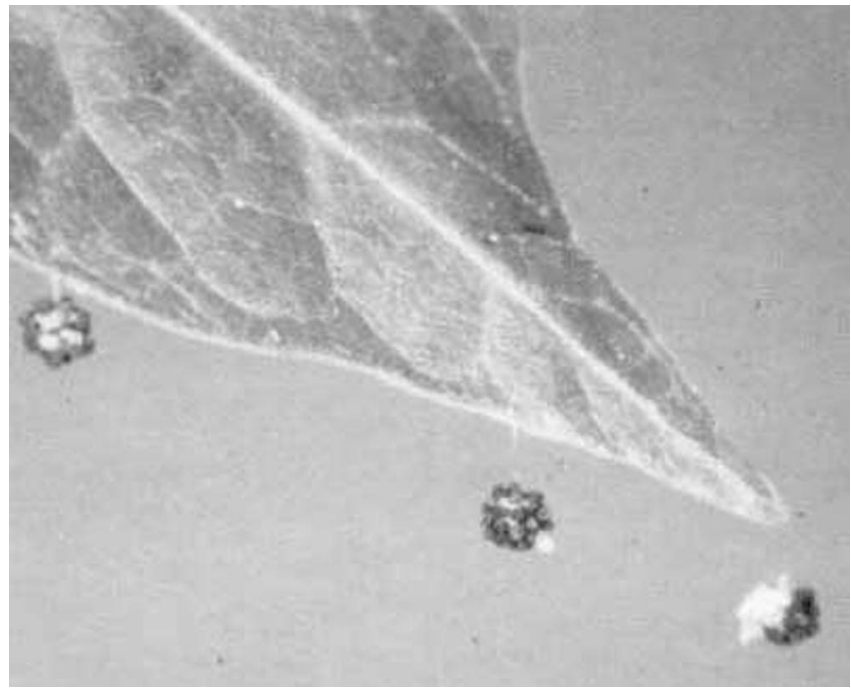

Figure 1. Eggs of Calleida decora (Fabricius), a ground beetle. Credits: Photograph by: Shepard, reproduced from McWhorter et al. by permission of the editor, Journal of Agricultural Entomology

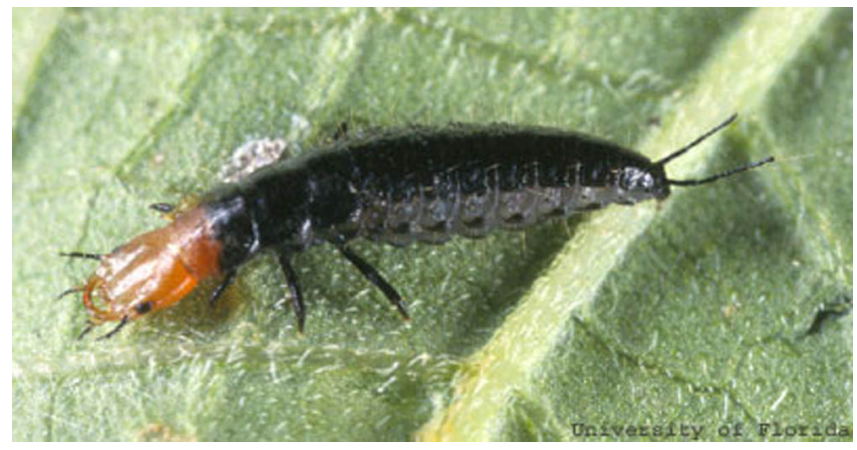

Figure 2. Larva of Calleida decora (Fabricius), a ground beetle. Credits: Photograph by: Lyle Buss, University of Florida

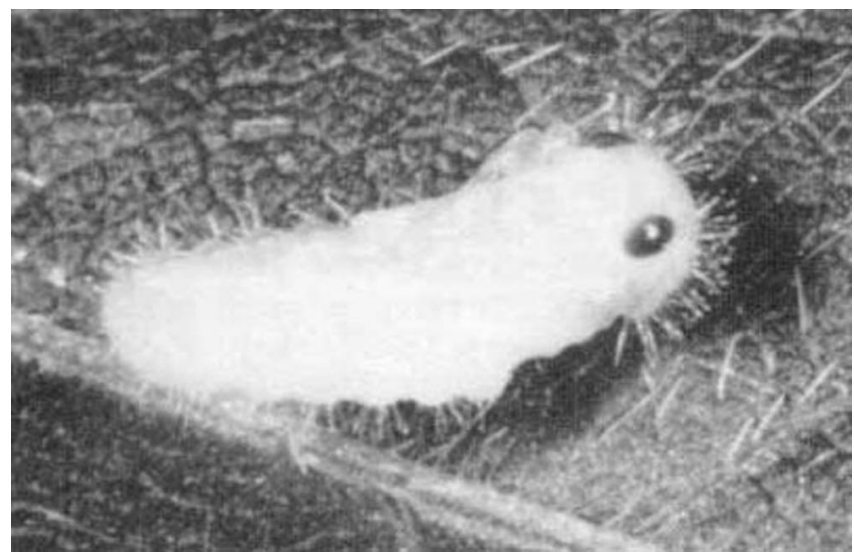

Figure 3. Pupa of Calleida decora (Fabricius), a ground beetle. Credits: Photograph by: Shepard, reproduced from McWhorter et al. by permission of the editor, Journal of Agricultural Entomology.

Adults are slender, 7 to $10 \mathrm{~mm}$ long, 2.5 to 3.5 $\mathrm{mm}$ wide. Head and elytra are green or blue- black, thorax and legs yellowish-red with tips of femora and tarsi dark. Antennae are dark with three or four basal segments lighter.

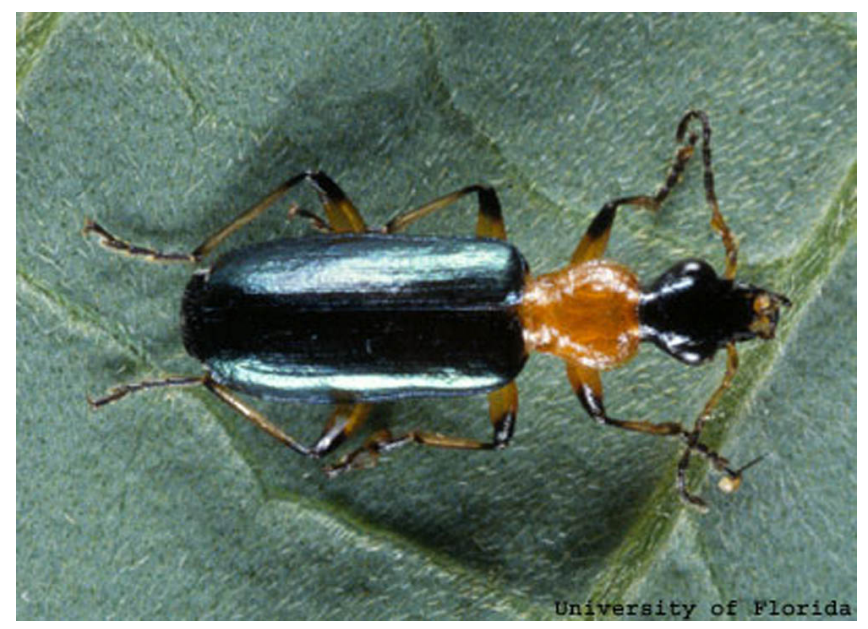

Figure 4. Adult Calleida decora (Fabricius), a ground beetle. Credits: Photograph by: Lyle Buss, University of Florida.

Males have a double row of papillate hairs on the undersurface of the first three protarsal segments and first two metatarsal segments (appearing white), but female tarsi are pubescent (straw-colored) (Horn 1882, McWhorter et al. 1984).

\section{Biology}

Caged adult females live an average of 230 days with a mean preovipositional period of 11 days and lay an average of 800 eggs (McWhorter et al. 1984). While an egg is still held by the abdominal tip, the female covers it with sand or dust particles, and binds it with silken thread to form a purse. The "egg purse" is attached to a leaf by a silken thread. Developmental times at 22 to $28^{\circ} \mathrm{C}$ for eggs, larvae, and pupae are approximately four to six, 12 to 18 , and four to six days, respectively (McWhorter et al. 1984; unpub. data 1973, 1982). Larvae are predaceous except while undergoing sclerotization following hatching and molting (McWhorter et al. 1984). They are highly cannibalistic and must be reared in individual containers. They feed readily on lepidopterous eggs as well as small larvae. 


\section{Economic Importance}

On soybeans, populations were estimated as high as 5400/ha in Gadsden County, Florida (Neal 1974) and 9600/ha in Alachua County, Florida (Elvin 1983). C. decora adults and larvae have been observed feeding on velvetbean caterpillar, $A$. gemmatalis Hübner; cabbage looper, Trichoplusia ni Hübner; soybean looper, Pseudoplusia includens (Walker); and other lepidopterous larvae (Whitcomb and Bell 1964; McCarty et al. 1980; McWhorter et al. 1984; unpublished data 1973, 1982).

Over $10 \%$ of the total insect predation (almost $20 \%$ during one season) of $A$. gemmatalis larvae (1st to 4th instar) artificially placed on soybean foliage was by $C$. decora. Of the 21 predation observations involving $C$. decora during a total of four seasons, 19 were by larvae and two by adults (Elvin 1983, unpub. data 1974). Adult $C$. decora, confined in small field cages on potted soybeans, consumed an average of 6.4 small (1st to $3 \mathrm{rd}$ instar) $P$. includens larvae/24 hr (Richman et al. 1980).

\section{Survey and Detection}

Larval and adult populations on crops may be sampled by direct observation or examination, vacuum sampling, sweeping, shaking, or beating of the foliage. This species should not be confused with destructive leaf beetles of similar size and coloration.

\section{Selected References}

Elvin MK. 1983. Quantitative estimation of rates of arthropod predation on velvetbean caterpillar (Anticarsia gemmatalis Hübner) eggs and larvae in soybeans. Ph.D. Dissertation, University of Florida. 249 pp.

Erwin TL, Whitehead DR, Ball GE. 1977. Family 4 Carabidae In Arnett RH Jr. Checklist of the beetles of North and Central America and the West Indies. Vo1.1, The ground beetles, water beetles, and related groups. Gainesville: Flora and Fauna Publications. 68 pp.

Hasse WL. 1971. Predaceous arthropods of Florida soybean fields. M.S. Thesis, University of Florida. 67 pp.
Horn GH. 1882. Synopsis of the species of the tribe Lebiini. Transactions of the American Entomological Society 10: 126-164.

McCarty MT, Shepard M, Turnipseed SG. 1980. Identification of predaceous arthropods in soybeans by using autoradiography. Environmental Entomology 9: 199-203.

McWhorter RE, Grant JF, Shepard M. 1984. Life history of a predator, Calleida decora, and the influence of temperature on development. Journal of Agricultural Entomology 1: 68-77.

Neal TM. 1974. Predaceous arthropods in the Florida soybean agroecosystem. M.S. Thesis, University of Florida. 194 pp.

Richman DB, Hemenway RC Jr, Whitcomb WH. 1980. Field cage evaluation of predators of the soybean looper, Pseudoplusia includens (Lepidoptera: Noctuidae). Environmental Entomology 9: 315-317.

Whitcomb WH, Bell K. 1964. Predaceous insects, spiders and mites of Arkansas cotton fields. Arkansas Agricultural Experiment Station Bulletin 690: 1-84. 